\title{
APRESENTAÇÃO DO DOSSIÊ - LUTAS, RESISTÊNCIAS E SABERES \\ POPULARES: A EDUCAÇÃO COMO CAMINHO \\ PARA A EMANCIPAÇÃO
}

\section{DOSSIER PRESENTATION - STRUGGLES, RESISTANCE AND \\ POPULAR KNOWLEDGE: EDUCATION AS PATH TO EMANCIPATION}

\author{
Marciano Antonio da Silva ${ }^{1}$ \\ Elba Ravane Alves Amorim² \\ Elizabeth Maria da Silva ${ }^{3}$
}

Em tempos de negacionismo da ciência e instalação de um sistema de necropolítica (MBEMBE, 2020) que extermina - em sua maioria - a população preta e pobre do nosso país, situar as lutas e resistências que se encontram fundamentadas nos saberes populares, constituise enquanto um ato de subversão e denúncia diante da operacionalização de um regime de opressão e exclusão. Deste modo, ao passo que assumimos esse compromisso político e pedagógico, buscamos constituir outras experiências sociais, mais justas e fundamentadas nos princípios de respeito e equidade.

O exercício teórico-epistemológico de discutir tais questões na academia não apenas traz à tona questões que historicamente estiveram invisibilizadas ou mesmo marginalizadas em nome de uma ciência que ainda se encontra assentada nos cânones do conhecimento hegemônico, mas também reacende nossas utopias, nos fazendo esperançar em meio um cenário

\footnotetext{
1 Doutorando e Mestre em Educação pelo Programa de Pós-Graduação em Educação Contemporânea da Universidade Federal de Pernambuco - Centro Acadêmico do Agreste (UFPE/PPGEDUC/CAA). e-mail: marcianoantoniosilva@gmail.com

${ }^{2}$ Doutoranda em Educação Contemporânea pelo Programa de Pós-Graduação em Educação Contemporânea da Universidade Federal de Pernambuco - Centro Acadêmico do Agreste (UFPE/PPGEDUC/CAA). Mestra em Direitos Humanos pela Universidade Federal de Pernambuco. e-mail: professoraelbaravane @gmail.com

${ }^{3}$ Gestora na Secretaria de Educação do município do Recife-PE. Doutora em Educação pela Universidad de Salamanca- USAL/ Espanha. Mestra em Educação pela Universidade Federal de Pernambuco- CAA (2014). email: elizabethmsilvan@gmail.com
} 


\section{Revista \\ Debates Insubmissos}

adverso. Tal noção, encontra base no pensamento profético proposto por Freire (2000), compreendido também enquanto um pensamento utópico, que implica a denúncia de como estamos vivendo, assim como o anúncio de como poderíamos viver (FREIRE, 2020).

Seguindo este viés, ao denunciarmos os efeitos nefastos provocados pela pandemia da COVID-19, assim como à crise institucional e a política econômica neoliberal que tem resultado num cenário desolador, onde mais de 20 milhões de pessoas declaram que passam até $24 \mathrm{~h}$ sem ter o que comer, buscamos não apenas evidenciar a política genocida implantada no Brasil, mas também construir alternativas para pensar outras realidades. Ainda segundo Freire (2000, p. 54) “[...] o pensamento profético não apenas fala do que pode vir, mas, falando de como está sendo a realidade, denunciando-a, anuncia um mundo melhor" [grifos do autor].

$\mathrm{Na}$ confluência desses acontecimentos, com o fechamento das escolas milhões de crianças ficaram sem o reforço alimentar que a merenda escolar representa. Crianças sem alimentação e sem conectividade, refletem o alargamento dos abismos sociais históricos que vinham sendo superados com políticas de educação que asseguravam alimentação, transporte e que vinculavam a transferência de renda do Bolsa Família à frequência escolar. Vivencia-se um processo de desmantelamento das políticas públicas que tinham por objetivo assegurar o direito à educação e à alimentação das camadas populares, o que inviabiliza o próprio direito à vida e à dignidade.

Diante da omissão do Estado, articulações entre movimentos de trabalhadores/as, movimentos inter-religiosas e identitários desenvolveram projetos na tentativa de aliviar a fome de comida e de educação do povo. Nesse contexto, é no diálogo entre academia e movimentos sociais que se busca manter firme o esperançar sem esperar, pois, crianças desmaiam de fome enquanto gestores pensam se e como entregam kits com a merenda escolar, se as aulas permanecem remotas ou retornam a presencialidade, assim, nas palavras de Paulo Freire, encontra-se a base para a práxis:

É preciso ter esperança, mas ter esperança do verbo esperançar; porque tem gente que tem esperança do verbo esperar. E esperança do verbo esperar não é esperança, é espera. Esperançar é se levantar, esperançar é ir atrás, esperançar é construir, 
esperançar é não desistir! Esperançar é levar adiante, esperançar é juntar-se com outros para fazer de outro modo (FREIRE, 1992, p. 54).

Para fortalecer práticas transformadoras e esperançar nesse contexto onde claramente há um projeto para acabar com a escola e a universidade pública, a Revista Debates Insubmissos publica o dossiê "Lutas, resistências e saberes populares: a educação como caminho para a emancipação" com artigos resultado de pesquisas comprometidas com uma educação crítica e emancipadora.

Caminhando nessa direção, o artigo "A educação do campo como modo de resistência à investida neoliberal: relato de experiência de um fazer escola no assentamento do MST" de autoria da Professora Doutora Marcia Roxana Cruces Cuevas (UFES) e da Pedagoga Maria de Fátima Miguel Ribeiro (UFES), reacende um debate em torno da investida neoliberal a partir do processo de mercantilização da educação e das políticas públicas. Diante de um cenário de fechamento as escolas do campo, as autoras analisam as lutas e resistências forjadas por educadores/as e educandos/as da EEEF Paulo Damião Tristão Purinha, do assentamento Sezínio Fernandes de Jesus, no município de Linhares, no estado do Espírito Santo.

O segundo artigo, intitulado "Cartografias dos movimentos religiosos e da participação de jovens nas ações em defesa dos direitos humanos" da Professora Doutora Maria Isabel Silva Bezerra Linhares (UVA), da Professora Doutora Nadja Rinelle Oliveira de Almeida (UVA) e da Pedagoga Heline Maria Sousa de Carvalho (UVA), traz uma discussão acerca dos sentidos e significados constituídos a partir da participação de jovens nos movimentos religiosos.

Nesse movimento, a Professora Doutora Maria do Socorro Silva (UFCG) apresenta o artigo "Educação popular como teoria e prática da educação do campo: diálogos com Paulo Freire", onde realiza uma revisão de literatura sobre a contribuição de Paulo Freire e da Educação Popular para o Movimento Político-Pedagógico-Epistêmico da Educação do Campo, que emerge no Brasil no final da década de 1990, como contraposição ao projeto societário hegemônico e ao modelo de Educação Rural.

O último artigo do dossiê tem como título "Ponto de partida: alimentando diálogos, reflexões e intervenções educativas no Alto do Moura, acerca das diversidades, na 
perspectiva da diferença e da interseccionalidade" de autoria da Professora Doutora Maria do Carmo Gonçalo Santos (UFPE/CAA) e do Professor Doutor Everaldo Fernandes da Silva (UFPE/CAA), fruto de um trabalho educativo do grupo "Ponto de Partida", desenvolvido na Comunidade do Alto do Moura, em Caruaru-PE, trata dos diálogos, reflexões e intervenções acerca das diferenças. Trata-se de um trabalho de extensão que articula sujeitos, espaços formativos e saberes.

Em suma, os artigos que compõem este dossiê, para além de importantes contribuições na produção do conhecimento científico, trazem consigo um comprometimento ético, político e pedagógico com os saberes populares, uma vez que reconhecem as lutas e resistências que emergem dos diferentes territórios.

Assim sendo, esperamos que as reflexões tecidas nesses trabalhos reacendam nossos sonhos e utopias, conduzindo novas possibilidades de intervenção no mundo.

Boa leitura a todos, todas e todes!

\section{REFERÊNCIAS}

FREIRE, Paulo. Pedagogia da Esperança - Um reencontro com a Pedagogia do Oprimido. Rio de Janeiro: Paz de Terra, 1992

FREIRE, Paulo. Pedagogia da Indignação: Cartas Pedagógicas e Outros Escritos. São Paulo: Editora UNESP, 2000.

MBEMBE, Achille. Necropolítica. Melusina, 2020. 